\title{
HTRA1 wt Allele
}

National Cancer Institute

\section{Source}

National Cancer Institute. HTRA1 wt Allele. NCI Thesaurus. Code C101310.

Human HTRA1 wild-type allele is located in the vicinity of 10q26.3 and is approximately 53 $\mathrm{kb}$ in length. This allele, which encodes serine protease HTRA1 protein, is involved in the mediation of proteolysis. Variations in the promoter of the gene are associated with agerelated macular degeneration type 7. Mutation of the gene is associated with cerebral autosomal recessive arteriopathy with subcortical infarcts and leukoencephalopathy. 